\title{
Sexually Transmitted Infections and Treatment Practices: A Comparative Study of HIV Discordant and Concordant Couples Accessing Care at Comprehensive Health Centers in Anambra State, Nigeria
}

\author{
Adaeze N. Anaekwe ${ }^{1}$, Chidebe O. Anaekwe ${ }^{1}$, Chinomnso C. Nnebue $^{1,2^{\star}}$, \\ Adaeze O. Okonkwo ${ }^{1}$ and Chigozie O. Ifeadike ${ }^{1}$ \\ ${ }^{1}$ Department of Community Medicine, Nnamdi Azikiwe University Teaching Hospital, Nnewi, Nigeria. \\ ${ }^{2}$ Department of HIV Care, Nnamdi Azikiwe University Teaching Hospital, Nnewi, Nigeria.
}

Authors' contributions

This work was carried out in collaboration between all authors. Authors ANA and COA were involved in the design and the implementation of the study. Author CCN was involved in the design, analysis of data, interpretation of results and write up of this study, while authors $A O O$ and $\mathrm{COI}$ were involved in the implementation of the study. All authors read and approved the final manuscript.

Article Information

DOI: $10.9734 / I S R R / 2017 / 34741$

Editor(s):

(1) Kailash Gupta, Division of AIDS, NIAID, NIH, USA

Reviewers:

(1) Edmund J. Kayombo, Muhimbili University of Health and Allied Sciences, Tanzania.

(2) Joyce Kinaro, University of Nairobi, Kenya.

Complete Peer review History: http://www.sciencedomain.org/review-history/19923

Original Research Article

Received $8^{\text {th }}$ June 2017

Accepted $3^{\text {rd }}$ July 2017

Published $7^{\text {th }}$ July 2017

\section{ABSTRACT}

Background: The prevalence of sexually transmitted infections (STI) among HIV affected couples has implications for containment of infectiousness of HIV. Understanding correlates of STI among discordant couples could boost the effectiveness of antiretroviral interventions.

Objective: To compare the STI occurrence and treatment practices of HIV discordant and concordant couples in comprehensive health centers in Anambra state, Nigeria.

Materials and Methods: This was a cross-sectional comparative study of 289 (148 HIVconcordant and 141 HIV-discordant) couples, selected by multistage sampling technique. Data 
were collected by interview using semi-structured questionnaire and analysed with statistical package for social sciences version 22.0. Tests of statistical significance were done using chisquare and fishers exact tests and $p$ values $\leq 0.05$ were significant.

Results: The mean ages $\pm S D$ were $41.1 \pm 19.3$ years for males and $34.4 \pm 9.1$ years for female, while $142(49.3 \%)$ concordant couples, compared to $122(42.4 \%)$ discordant counterparts were sexually active $(p=0.001), 61(22.9 \%)$ of these do not use condoms ( $p=0.401), 104(35.9 \%)$ had previously treated STI. Gonorrhoea in males 61(89.7\%) and candidiasis in females $25(65.8 \%)$ were the commonest STI. More concordant couples had both partners ever treated STI $(p=0.004)$. Frequency of sexual intercourse $(p=0.007)$ and occasional or never used condoms $(p=0.037)$ were associated with more history of previous STI treatment.

Conclusion: This study found that more concordant couples had both partners ever treated STI, while frequent sexual intercourse and occasional or never use of condoms, both more in discordant than concordant couples, were associated with more history of previous STI treatment. We therefore recommend couple-level STI interventions that combine treatment and behavioral change communication.

Keywords: Couples; sero-discordance; HIV; sexually transmitted infections; Nigeria.

\section{INTRODUCTION}

Sexually transmitted infections in one or both partners remains one of the most-documented risk factors for HIV infection [1,2,3]. These STIs are associated with significant increase in HIV transmission risk $[3,4,5,6,7]$. Studies have also documented that sexual act is the main route of HIV transmission, often facilitated by STIs through the breaching of protective mucosal barriers and recruiting susceptible immune cells such as macrophages and CD4 T-helper cells, to the site of infection $[1,7,8,9,10]$.

Empirical studies show that a significant number of persons living with HIV/AIDS (PLWHA), continue to engage in risky sexual behaviors $[11,12,13,14,15]$. It has been reported that epidemics of HIV are sustained and propagated by new cases of infection which result from transmission from infected persons to uninfected susceptible individuals $[11,13]$. The transmission risk of HIV among discordant couples may be enhanced by sexually transmitted infections, accounting for a large proportion of new HIV-1 infections $[16,17]$. Several studies have reported that treatment of STIs often lowers genital shedding of HIV-1 and thus recommended that HIV positive persons could play a critical role in HIV prevention if they ensure sexual responsibility $[14,18,19]$.

A comprehensive understanding of the underlying mechanisms and correlates of highrisk sexual behavior among PLWHA remains a priority area in public health research. To our knowledge, no previous studies conducted in our study area attempted a comparison among HIV discordant and concordant couples vis a vis STI and its treatment practices. It is expected that our study findings would aid in bridging the knowledge gaps that presently exist in the area of HIV discordance. Thus the index study compared the STI occurrence and treatment practices of HIV discordant and concordant couples in comprehensive health centers in Anambra state, Nigeria.

\section{MATERIALS AND METHODS}

\subsection{Study Area, Period and Design}

This institution based cross sectional comparative study was conducted between January and April 2013 at two comprehensive health centers (CHCs) in Anambra state, Nigeria [20]. Each of the centers hosts a 30 to 35 bed facility which employs various cadre of health workers. At the time of this study the first facility had 482 PLWHA accessing care, runs a HIV clinic twice a week and has an average weekly attendance of 60 patients per clinic. One hundred and twenty of the couples are in discordant relationships, 140 couples are in a concordant relationships, while seventy people are single adults and 12 are below 18 years. The second facility operates a linkage system with the first $\mathrm{CHC}$, as both facilities are manned by the same group of doctors on a rotational basis. The center presently has 700 PLWHA accessing care, runs a HIV clinic twice weekly and an average weekly attendance of 100 patients. One hundred and eighty of the couples are in discordant relationships, 180 couples are concordant, 120 adult singles and 40 teenagers. 


\subsection{Study Population and Sampling Technique}

The target population consisted of the HIV discordant and concordant couples accessing care at the CHCs. Couples who had been in a sero-discordant/ concordant sexual relationship for at least six months; both partners had disclosed his/ her status to the other partner and both partners were aged 18 years or older met the inclusion criteria. Those in sero-discordant /concordant relationships for more than six months who did not give their consent were excluded.

Minimum sample size was calculated using formula for comparison of 2 proportions [21]. Proportion of sexually transmitted infections occurrence and treatment practices in discordant couples $=50 \%$ since there is no documented literature comparing sexually transmitted infections occurrence and treatment practices of discordant and concordant couples, were considered to determine the final sample size at 131. Anticipating a response rate of $90 \%,(f=\%$ of response $=90 \%(0.9))$ to make up for nonresponse, the study sample size was calculated as $n / f[22]=131 / 0.9=145$ couples per group.

Multistage sampling technique was used to conduct this study. Firstly, from the four comprehensive health centers in the State, two were chosen by simple random sampling using balloting. Secondly, from the clinics, the sampling frames of the discordant and concordant couples accessing care were obtained. This consisted of the lists of these couples accessing care at these clinics. At the time of the study, the total number of discordant couples at the two comprehensive centers was 300 while the number of concordant couples was 320 . For the discordant couples, simple random sampling using a table of random numbers was employed to select the 145 couples from the sampling frame. Same was done to obtain the sample size from the concordant couples sampling frame.

\subsection{Data Collection and Analysis}

Pre-tested, interviewer-administered semistructured questionnaires. The questionnaire for this study was adapted from that used by the Human Sciences Research Council South Africa and the Global Network of people living with HIV/AIDS [23]. All those who consented but had their appointments fall within the study period were interviewed while those whose appointments fell outside the study period, were interviewed at a convenient time and place.

To ensure data quality, training of data collection team, field monitoring of data collection was done. Meeting of data collection team at the end of every day to share experiences, submit completed forms and solve field problems was ensured. At the end of the study, one of the questionnaires could not be traced during analysis hence only 289 questionnaires were analysed. The data were reviewed, entered into the computer and were cleaned by carrying out range as well as by consistency checks. Descriptive and analytical statistics of the data were carried out using statistical package for social sciences (SPSS) Windows version 22.0 [24]. Descriptive data were presented as simple frequencies and percentages.

Frequencies of the variables was assessed using univariate analysis, while bivariate analysis using chi-square and fishers exact tests determined associations between variables, comparing concordant and discordant couples. Level of significance was set at $5 \%$ or less.

\subsection{Ethical Consideration}

The study has been examined and approved by the Nnamdi Azikiwe University Teaching Hospital Ethics Committee Nnewi, Nigeria. A written informed consent was also obtained from each participant for the conduct and publication of this research study and assurance of confidentiality given. Study participants were free to refuse or withdraw from the study at any time without any penalty. The study objectives were explained to participants prior to interviews. All authors hereby declare that the study has been performed in accordance with the ethical standards laid down in the 1964 Declaration of Helsinki.

\section{RESULTS}

Table 1 shows the socio- demographic characteristics of respondents. Data were obtained from 289 respondents, consisting of 148 HIV-concordant, and 141 HIV-discordant couples. The mean ages $\pm S D$ of all, male, and female respondents were $37.8 \pm 9.8,41.1 \pm 19.3$, and $34.4 \pm 9.1$ years respectively. In all but one couple, the male partners were older than their female spouses, with $36-40$ years as the modal male age group, for both sets of couples, while 25-30 years was the modal female age group for both sets of couples. 
Table 2 shows the sexual behavior and practices of concordant and discordant couples. One hundred and forty two (49.3\%) concordant couples, compared to $122(42.4 \%)$ discordant counterparts were sexually active $\left(x^{2}=7.3, p=\right.$ $0.001)$. Sixty one $(22.9 \%)$ of them do not use condoms ( $x 2=0.705, p=0.401)$. At least one of the partners in $22(7.5 \%)$ concordant couples, compared to $8(3 \%)$ discordant counterparts had arousal difficulty $(\mathrm{x} 2=4.525, \mathrm{p}=0.033)$. More discordant couples had sexual concerns to share $\left(x^{2}=3.827, p=0.05\right)$.

Table 3 summarizes the history of occurrence and treatment of STI among concordant and discordant couples. About one-third of the couples $104(35.9 \%)$ had previously treated STIs, with gonorrhoea in males $61(89.7 \%)$, and candidiasis in females $25(65.8 \%)$, as the most prevalent STI. There were more concordant couples with both partners having previously treated STI $(x 2=13.42, p=0.004)$, but there was no statistically significant difference in the type of STI, for males $(p=0.668)$ and females ( $p$ $=0.714$ ) respectively.

Table 4 shows the relationship between sexual behavior and occurrence of STI amongst respondents. Frequency of sexual intercourse $\left(\left(x^{2}=7.26, p=0.007\right)\right.$ and occasional or never used condoms $(x 2=4.36, p=0.037)$ respectively, were associated with more history of previous STI treatment.

Table 1. Sociodemographic characteristics of HIV discordant and concordant couples in comprehensive health centers in Anambra state, Nigeria by relationship status ( $N=578$ )

\begin{tabular}{|c|c|c|c|c|c|c|}
\hline \multicolumn{2}{|c|}{ Characteristics } & \multicolumn{2}{|c|}{ Concordant couples } & \multicolumn{2}{|c|}{ Discordant couples } & \multirow{2}{*}{$\begin{array}{l}\text { Group } \\
\text { total } \\
\text { n (100\%) }\end{array}$} \\
\hline & & $\begin{array}{l}\text { Male } \\
\text { concordant } \\
\text { n (\%) }\end{array}$ & $\begin{array}{l}\text { Female } \\
\text { concordant } \\
\text { n (\%) }\end{array}$ & $\begin{array}{l}\text { Male } \\
\text { discordant } \\
\text { n (\%) }\end{array}$ & $\begin{array}{l}\text { Female } \\
\text { discordant } \\
\text { n (\%) }\end{array}$ & \\
\hline \multirow{8}{*}{$\begin{array}{l}0 \\
\frac{0}{3} \\
0 \\
\frac{0}{0} \\
0 \\
0 \\
\frac{0}{4}\end{array}$} & $18-24$ & $0(0.0)$ & $18(85.7)$ & $0(0.0)$ & $3(14.3)$ & $21(100)$ \\
\hline & $25-29$ & $21(13.4)$ & $59(37.6)$ & $17(10.8)$ & $60(38.2)$ & $157(100)$ \\
\hline & $30-34$ & $36(35.6)$ & $28(27.7)$ & $20(19.9)$ & $17(16.8)$ & $101(100)$ \\
\hline & $35-39$ & $36(29.8)$ & $14(11.6)$ & $43(35.5)$ & $28(23.1)$ & $121(100)$ \\
\hline & $40-44$ & $18(34.6)$ & $10(19.2)$ & $16(30.8)$ & $8(15.4)$ & $52(100)$ \\
\hline & $45-49$ & $18(25.4)$ & $15(21.1)$ & $23(32.4)$ & $15(21.1)$ & $71(100)$ \\
\hline & $50-54$ & $12(48.0$ & $2(8.0)$ & $8(32)$ & $3(12)$ & $25(100)$ \\
\hline & $\geq 55$ & 7 (48.3) & $2(10.5)$ & $13(47.4)$ & $7(21.0)$ & $30(100)$ \\
\hline \multirow{4}{*}{ 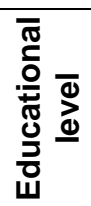 } & $\mathrm{Nil}$ & $1(20.0)$ & $0(0.0)$ & $3(60.0)$ & $1(20.0)$ & $5(100)$ \\
\hline & Primary & $50(32.0)$ & $36(23.1)$ & $34(21.8)$ & $36(23.1)$ & $156(100)$ \\
\hline & Secondary & $58(21.4)$ & $83(30.6)$ & $56(20.7)$ & $74(27.3)$ & $271(100)$ \\
\hline & Tertiary & $39(26.7)$ & $29(19.9)$ & $48(32.9)$ & $30(20.5)$ & $146(100)$ \\
\hline \multirow{5}{*}{ 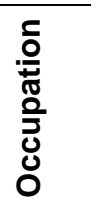 } & Farmer & $12(38.7)$ & $4(12.9)$ & $10(32.3)$ & $5(16.1)$ & $31(100)$ \\
\hline & Civil Serv. & 97 (28.2) & $81(23.6)$ & $82(23.8)$ & $84(24.4)$ & $344(100)$ \\
\hline & Trader & $28(24.5)$ & $30(26.3)$ & $32(28.1)$ & $24(21.1)$ & $114(100)$ \\
\hline & Others & $11(15.7)$ & $18(25.7)$ & $16(22.9)$ & $25(35.7)$ & $70(100)$ \\
\hline & Unemployed & $0(0.0)$ & $14(77.8)$ & $1(5.5)$ & $3(16.7)$ & $18(100)$ \\
\hline \multirow{2}{*}{ 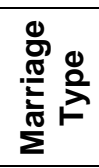 } & Monogamy & $132(50.3)$ & & $130(49.6)$ & & $262(100)$ \\
\hline & Polygamy & $15(55.6)$ & & $12(44.4)$ & & $27(100)$ \\
\hline \multirow{7}{*}{ 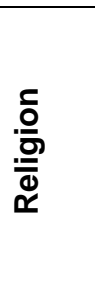 } & Pentecostal & $34(47.8)$ & & $37(52.2)$ & & $71(100)$ \\
\hline & Anglican & $39(49.4)$ & & 40 (50.6) & & $79(100)$ \\
\hline & Rom. Cath. & 56 (53.8) & & 48 (46.2) & & $104(100)$ \\
\hline & Jeh. Wit & $3(60.0)$ & & $2(40.0)$ & & $5(100)$ \\
\hline & Sabbath & $9(52.9)$ & & $8(47.1)$ & & $17(100)$ \\
\hline & Moslem & $0(0.0)$ & & $1(100)$ & & $1(100)$ \\
\hline & Trad. & 7 (63.6) & & $4(36.4)$ & & $11(100)$ \\
\hline
\end{tabular}


Table 2. Sexual practices of HIV discordant and concordant couples in comprehensive health centers in Anambra state, Nigeria

\begin{tabular}{|c|c|c|c|c|c|c|}
\hline & & $\begin{array}{l}\text { Concordant } \\
\text { couples } \\
\mathrm{n}(\%)\end{array}$ & $\begin{array}{l}\text { Discordant } \\
\text { couples } \\
\text { n }(\%)\end{array}$ & $\begin{array}{l}\text { Chi- } \\
\text { square } \\
\text { statistic }\end{array}$ & $\begin{array}{l}\text { Degrees } \\
\text { of } \\
\text { freedom }\end{array}$ & $\begin{array}{l}P- \\
\text { value }\end{array}$ \\
\hline Sexually active & Yes & $142(49.3)$ & $122(42.4)$ & 7.3 & 1 & 0.001 \\
\hline $\begin{array}{l}\text { Frequency of sexual } \\
\text { activity (Weekly) }\end{array}$ & $\begin{array}{l}\geq 3 \\
<3\end{array}$ & $\begin{array}{l}56(20.9) \\
85(31.7)\end{array}$ & $\begin{array}{l}63(23.9) \\
64(23.9)\end{array}$ & 2.65 & 1 & 0.104 \\
\hline Condom use & $\begin{array}{l}\text { Yes } \\
\text { No }\end{array}$ & $\begin{array}{l}110(41.4) \\
29(10.9)\end{array}$ & $\begin{array}{l}95(35.7) \\
32(12.0)\end{array}$ & 0.705 & 1 & 0.401 \\
\hline $\begin{array}{l}\text { One or both partners } \\
\text { has arousal difficulty }\end{array}$ & $\begin{array}{l}\text { Yes } \\
\text { No }\end{array}$ & $\begin{array}{l}20(7.5) \\
120(44.9)\end{array}$ & $\begin{array}{l}8(3.0) \\
119(44.6)\end{array}$ & 4.525 & 1 & 0.033 \\
\hline $\begin{array}{l}\text { Satisfaction with sexual } \\
\text { relationship }\end{array}$ & $\begin{array}{l}\text { Yes } \\
\text { No }\end{array}$ & $\begin{array}{l}114(39.7) \\
32(11.1)\end{array}$ & $\begin{array}{l}117(40.8) \\
24(8.4)\end{array}$ & 1.1 & 1 & 0.295 \\
\hline $\begin{array}{l}\text { Have sexual concerns } \\
\text { to share }\end{array}$ & $\begin{array}{l}\text { Yes } \\
\text { No }\end{array}$ & $\begin{array}{l}6(2.1) \\
137(48.9)\end{array}$ & $\begin{array}{l}4(5.0) \\
123(43.9)\end{array}$ & 3.827 & 1 & 0.05 \\
\hline
\end{tabular}

Table 3. History of occurrence and treatment of STI among HIV discordant and concordant couples in comprehensive health centers in Anambra state, Nigeria

\begin{tabular}{|c|c|c|c|c|c|c|}
\hline & & $\begin{array}{l}\text { Concordant } \\
\text { couples } \\
\mathrm{n}(\%) \\
\end{array}$ & $\begin{array}{l}\text { Discordant } \\
\text { couples } \\
\text { n }(\%)\end{array}$ & $\begin{array}{l}\text { Chi- } \\
\text { square } \\
\text { statistic }\end{array}$ & $\begin{array}{l}\text { degrees } \\
\text { of } \\
\text { freedom }\end{array}$ & $\begin{array}{l}P- \\
\text { value }\end{array}$ \\
\hline \multirow[t]{4}{*}{$\begin{array}{l}\text { Previous STI } \\
\text { treatment }\end{array}$} & $\begin{array}{l}\text { Both partners } \\
\text { treated }\end{array}$ & $25(8.7)$ & $6(2.1)$ & 13.42 & 3 & 0.004 \\
\hline & $\begin{array}{l}\text { Both partners not } \\
\text { treated }\end{array}$ & $89(30.8)$ & 96 (33.2) & & & \\
\hline & $\begin{array}{l}\text { Only male } \\
\text { partner treated }\end{array}$ & $21(7.3)$ & $29(10.0)$ & & & \\
\hline & $\begin{array}{l}\text { Only female } \\
\text { partner treated }\end{array}$ & $13(4.5)$ & $10(3.5)$ & & & \\
\hline $\begin{array}{l}\text { STI type } \\
\text { (male partners) }\end{array}$ & $\begin{array}{l}\text { Gonorrhoea } \\
\text { Syphilis }\end{array}$ & $\begin{array}{l}32(48.5) \\
2(3.0)\end{array}$ & $\begin{array}{l}29(43.9) \\
3(4.5)\end{array}$ & $\begin{array}{l}\text { Fisher's } \\
\text { exact }\end{array}$ & & 0.668 \\
\hline STI type & candidiasis & $18(47.4)$ & 7 (18.4) & Fishers & & 0.714 \\
\hline (female partners) & genital warts & $8(21.10$ & $5(13.2)$ & exact & & \\
\hline
\end{tabular}

Table 4. Relationship between sexual behavior and occurrence of STI among HIV discordant and concordant couples in comprehensive health centers in Anambra state, Nigeria

\begin{tabular}{lllllll}
\hline Sexual behavior & \multicolumn{3}{c}{ Previous STI } & $\begin{array}{l}\text { Chi- } \\
\text { square }\end{array}$ & p-value \\
\cline { 2 - 5 } & & $\begin{array}{l}\text { Concordant } \\
\mathbf{n}(\%)\end{array}$ & $\begin{array}{l}\text { Discordant } \\
\mathbf{n}(\%)\end{array}$ & $\begin{array}{l}\text { Total } \\
\mathbf{n}(\mathbf{1 0 0} \%)\end{array}$ & \\
\hline Intercourse & $\geq 3$ times & $55(46.2)$ & $64(53.8)$ & $119(100)$ & 7.26 & 0.007 \\
frequency & $<3$ times & $45(30.2)$ & $104(69.8)$ & $149(100)$ & & \\
Condom use & $\begin{array}{l}\text { Frequently } \\
\text { /always }\end{array}$ & $16(26.2)$ & $45(73.8)$ & $61(100)$ & 4.36 & 0.037 \\
& $\begin{array}{l}\text { Occasionally } \\
\text { /never }\end{array}$ & $84(41.0)$ & $121(59.0)$ & $205(100)$ & & \\
\hline
\end{tabular}

\section{DISCUSSION}

This was a cross-sectional study that compared sexually transmitted infections occurrence and treatment practices of HIV discordant and concordant couples in the Comprehensive health centers in Anambra state, Nigeria. The index study reported that mean ages $\pm S D$ of all, male, and female respondents were $37.8 \pm 9.8,41.1 \pm$ 19.3 , and $34.4 \pm 9.1$ years respectively. This 
finding agrees with that of Guthrie et al. [1], where females were significantly younger than males.

The present study found a statistically significant difference in about half(49.3\%) of concordant couples, compared to (42.4\%) of discordant counterparts were sexually active The current research also showed that of these sexually active couples, about four in ten, (41.4\%) concordant couples as against (35.7\%) from discordant couples use condoms. These figures are higher than those reported by Kaiser et al., in Kenya, where only $16.3 \%$ of concordant couples and $6.6 \%$ of discordant couples had used condoms consistently in the last six months [25]. The inconsistency could be due to differences in background prevalence of STIs, existing STI treatment services, the research designs, nature of population and sample size used in our study and theirs [26].

From our study findings, gonorrhoea in males and candidiasis in females were the most prevalent STI. However, Guthrie et al. [1], in a study elsewhere, documented trichomonas and syphilis as the most prevalent infections.

The index study reported that more concordant couples had both partners previously treated of STI (8.7\%) compared with discordant couples $(2.1 \%)$. Generally, couples that had more frequent sexual intercourse, more in discordant couples $(53.8 \%)$ than concordant couples $(46.2 \%)$, had more previous history of STI treatment. This finding is in keeping with that made in a study by Freeman et al. [27], which linked a high incidence of sexually transmitted diseases to the frequency of sexual intercourse.

The current study also reported that the occasionally or never used condoms, more in discordant couples $(59 \%)$ than concordant couples $(41.0 \%)$, had more previous history of STI treatment. As expected, there is more consistent evidence that the previous history of STI treatment was associated with riskier sexual behavior (e.g., unprotected sex) $[1,28,29,30]$.

\section{CONCLUSIONS}

This study examined the sexually transmitted infections occurrence and treatment practices of HIV discordant and concordant couples in the Comprehensive health centers in a Southeastern state in Nigeria and found that couples that had more frequent sexual intercourse and those that occasionally or never used condoms, (more in discordant couples than concordant couples), had more history of previous STI treatment.

We therefore recommend that a couple- targeted STI interventions that combine treatment and behavioral change communication may be an important component in reducing STI prevalence, risky sexual behavior, and controlling the risk of HIV transmission in discordant couples. These should include: promotion of adoption of consistent safer sexual behavior, condom promotion, timely diagnosis and proper treatment of STIS.

\section{LIMITATIONS AND STRENGTH OF THE STUDY}

Firstly, studies based on self-reports of sexual issues through questionnaires are prone to a number of biases that could affect the validity and reliability of the results. Also, STI issues are very sensitive and could limit free expression of respondents, who may have given socially desirable answers. Assurance of confidentiality of the respondents, the training of research assistants to be painstaking in answering possible questions raised by respondents during data collection. Also, the simple and direct nature of the questions reduced these effects. However, a major strength of this study was the high response rate $(99.2 \%)$ was obtained from this study.

\section{CONSENT}

As per international standard or university standard, patient's written consent has been collected and preserved by the authors.

\section{ETHICAL APPROVAL}

As per international standard or university standard, written approval of Ethics committee has been collected and preserved by the authors.

\section{COMPETING INTERESTS}

Authors have declared that no competing interests exist.

\section{REFERENCES}

1. Guthrie BL, Kiarie JN, Morrison S, JohnStewart GC, Kinuthia J, Whittington WL, et al. Sexually transmitted infections 
among HIV-1-discordant couples. PLoS ONE; 2009.

Available:http://dx.doi.org/10.1371/journal. pone.0008276

[Last accessed on 2017 May, 4].

2. Cohen MS. Sexually transmitted diseases enhance HIV transmission: No longer a hypothesis. Lancet.1998;351:Suppl35-7.

3. Abu-Raddad LJ, Magaret AS, Celum C, Wald A, Longini I. M. Jr., Self SG, et al. Genital herpes has played a more important role than any other sexually transmitted infection in driving HIV prevalence in Africa. PLoS ONE. 2008;3: e2230.

4. McClelland RS, Sangare L, Hassan WM, Lavreys L, Mandaliya K Kiarie J, et al. Infection with trichomonas vaginalis increases the risk of HIV-1 acquisition. $J$ Infect Dis. 2007;195:698-702.

5. Wald A, Link K. Risk of human immunodeficiency virus infection in herpes simplex virus type 2-seropositive persons: a meta-analysis. J Infect Dis. 2002;185: 45-52.

6. Jiwatram-Negrón $\mathrm{T}$, El-Bassel $\mathrm{N}$. Systematic review of couple-based HIV intervention and prevention studies: Advantages, gaps, and future directions. AIDSBehav. 2014;18(10):1864-87.

7. Freeman EE, Weiss HA, Glynn JR, Cross PL, Whitworth JA, Hayes RJ, et al. Herpes simplex virus 2 infection increases HIV acquisition in men and women: Systematic review and meta-analysis of longitudinal studies. AIDS. 2006;20:73-83.

8. Salaudeen AG, Ojotule A, Durowade KA, Musa OI, Yusuf AS, Saka MJ. Condom use among HIV sero-concordant couples attending a secondary health facility in North-Central Nigeria. Niger J Basic Clin Sci. 2013;10:51-6.

Available:http://www.njbcs. net/text.asp?2013/10/2/51/122758

[Last accessed on 2017,May 4]

9. Kalichman SC, Pellowski J, Turner C. Prevalence of sexually transmitted coinfections in people living with HIV/AIDS: Systematic review with implications for using HIV treatments for prevention. Available:http://dx.doi.org/10.1136/sti.2010 .047514

[Last accessed on 2017,May 4]

10. Ward H, Ronn M. Contribution of sexually transmitted infections to the sexual transmission of HIV. CurrOpin HIV AIDS. 2010;5:305-10.
11. Adimora AA, Schoenbach V, Doherty I. HIV and African Americans in the southern United States: Sexual networks and social context. Sex Transm Dis. 2006;33(Suppl): S39-S45.

12. Le Pont F, Pech N, Boelle PY, Giraud A, Gilloire S. Halfe, et al. A new scale for measuring dynamic patterns of sexual partnership and concurrency: Application to three French Caribbean regions. Sex Transm Dis. 2003;30(1):6-9.

13. Sexual behavior among persons living with HIV in Uganda: Implications for policy and practice. PLOS One; 2014.

Available:http://dx.doi.org/10.1371/journal. pone.0085646

[Last accessed on 2017 May 4]

14. Wenger NS, Kusseling FS, Beck K, Shapiro MF. Sexual behavior of individuals infected with the human immunodeficiency virus. The need for intervention. Arch Intern Med. 1994;154:1849-54.

15. Cohen MS, Hosseinipour M. HIV treatment meets HIV prevention: Antiretroviral therapy as prophylaxis. In: Mayer K, Pizer $\mathrm{HF}$, eds. The AIDS pandemic; impact on science and society. New York: Elsevier Science. 2005;137:161.

16. Barbour JD, Sauer MM, Sharp ER, Garrison KE, Long BR, Tomiyama $\mathrm{H}$, et al. HIV-1/HSV-2 co-infected adults in early HIV-1 infection have elevated CD4+ T cell counts. PLoS One. 2007;2:e1080.

17. Boily MC, Baggley R, Wang L, Masse B, White RG, Hayes RJ, et al. Heterosexual risk of HIV-1 infection per sexual act: systematic review and meta-analysis of observational studies. Lancet. 2009;9:11829.

18. Bayer R. AIDS prevention-sexual ethics and responsibility. N Engl J Med. 1996; 334:1540-2.

19. Ghys PD, Fransen K, Diallo MO, EttiegneTraore V, Coulibaly IM, Yeboué KM. The associations between cervicovaginal HIV shedding, sexually transmitted diseases and immunosuppression in female sex workers in Abidjan, Cote d'Ivoire. AIDS. 1997;11:F85-93.

20. Dunukofia.

Available:http://en.wikipaedia.org/wiki/Dun ukofia

[Last accessed 2013, June 25]

21. Kirkwood B. Essentials of medical statistics. Blackwell Scientific Publications. $2^{\text {nd }}$ Edition. 2001;190. 
22. Araoye MO. Research methodology with statistics for health and social sciences. Nathadex Publications, Saw-Mill, llorin $2^{\text {nd }}$ Ed. 2008;115-122.

23. Questionnaire modified from that of Human Sciences Research Council South Africa and Global Network of people living with AIDS.

Available:www.stigmaindex.Org/.../

Summary-Booklet-on-Stigma-Index-

Survey\%20 South \%20 A

[Last accessed on 2014 Jan 14]

24. Statistical Package for Social Sciences (IBM SPSS) 22.0 version. Armonk NY: IBM United States. IBM Corp; 2013.

25. Kaiser R, Bunnell R, Hightower A, Kim AA, Cherutich $\mathrm{P}$, Mwangi $\mathrm{M}$, et al. Factors associated with HIV infection in married or cohabitating couples in Kenya: Results from a nationally representative study. PLoS ONE. 2011;6(3):e17842.

26. Sangani $P$, Rutherford $G$, Wilkinson D. Population-based interventions for reducing sexually transmitted infections, including HIV infection. Cochrane Database Syst Rev. 2004;CD001220.

27. Freeman E, Glynn JR. Factors affecting HIV concordancy in married couples in four African cities. AIDS. 2004;18(12):1715-21.

28. Tadesse M. Assessment of HIV discordance and associated risk factors among couples receiving HIV test in Dilla, Ethiopia. BMC Research Notes. 2014;7: 893.

DOI: 10.1186/1756-0500-7-893

29. Mason PR, Fiori PL, Cappuccinelli P, Rappelli P, Gregson S. Seroepidemiology of Trichomonas vaginalis in rural women in Zimbabwe and patterns of association with HIV infection. Epidemiol Infect. 2005;133: 315-323V.

30. Klinger EV, Kapiga SH, Sam NE, Aboud S, Chen CY, et al. A community-based study of risk factors for Trichomonas vaginalis infection among women and their male partners in Moshi urban district, Northern Tanzania. Sex Transm Dis. 2006;33: 712-8.

(c) 2017 Anaekwe et al.; This is an Open Access article distributed under the terms of the Creative Commons Attribution License (http://creativecommons.org/licenses/by/4.0), which permits unrestricted use, distribution, and reproduction in any medium, provided the original work is properly cited.

Peer-review history:

The peer review history for this paper can be accessed here: http://sciencedomain.org/review-history/19923 